Sign Systems Studies 36.1, 2008

\title{
Barthes's positive theory of the author
}

\author{
Harri Veivo \\ Semiotics, Institute for Art Research \\ P.O. Box 35, 00014 University of Helsinki, Finland \\ e-mail: harri.veivo@helsinki.fi
}

\begin{abstract}
While it is well known that Roland Barthes consecrated his last lecture series at the Collège de France to the theme of the preparation of a novel, it is less known that his first writings on literature focused on the same question, but from a less individual point of view. The interrogation that motivates Le Degré zéro de l'écriture (1953) and many of the essays in Essais critiques (1964) is the question of how to write, of what procedures one can follow in preparing a literary work of art. At the two ends of Barthes's career one finds the same themes of writing as action and of the writer's possibilities and motivations in writing. The article explores the hypothesis that there is ground for a positive theory of the author in Barthes's work. It seeks to discover similarities between writings from the early and the late period that concern three themes: (1) writing as action, (2) the deferral of its achievement, and (3) writing as representation. The article ends with a discussion on the relationships between Barthes's positive theory of the author and related important issues that have been discussed recently in literary criticism.
\end{abstract}

At the last stage of his life, during the short period as professor at the Collège de France, Roland Barthes spoke more and more explicitly of his desire to write a novel, focusing in his last series of lectures in 1978-1979 and 1979-1980 on the topic of la préparation du roman and working privately on plans for a novel the title of which was to be Vita Nova. Given that Barthes had published in 1968 the provocative essay La mort de l'auteur, it is not surprising that this enactment of a writer's role has given rise to a lively scholarly discussion. Interpretations vary. It is possible to see Barthes's project as a failure and a logical outcome of his work on the neuter and the related themes, such as silence and abstinence, for example (Comment 1991); as an 
existential choice of a specific form of life where the phantasm of writing a novel expresses devotion to literature (Compagnon 2002); or as a success, the outcome of which was not a novel, but the autobiographical prose published as the posthumous book Incidents in 1987 and preceded by the half-theoretical, half-literary essay Déliberations in the revue Tel Quel in 1979 (Knight 2002).

Even though the generic extension of Barthes's achievement as a writer is yet to be established - was he also a literary writer in addition to the largely recognized brilliant essayist? - it is clear that he has become an author in the strong sense of the word. As research develops, arguments become more and more backed up with references to Barthes's Oeuvres complètes and manuscripts and conjectures on his intentions and desires. This "authorialization" of Barthes as a writer goes often hand in hand with a re-evaluation of his career in the light of the themes and projects of the last period. While some researchers have argued that Barthes's career was a coherent one (Buffat 2002), others have interpreted Barthes's late interest in the writer's work and the desire, the will and the intentions it involves, as well as his confession-like statement of being tired of the (post)modern literature he had defended earlier, as an abandonment of the textual theory of the 1970s and even as a sheer negation of the theoretical projects of the earlier years (Brenner 1993).

What I am about to do is another type of analysis of Barthes and the question of the author. While it is well known that Barthes consecrated his last lecture series at the Collège de France to the theme of the preparation of a novel, and that he approached the topic by methodologically analysing his own phantasms of writing and the literary texts that resonated with them, it is less known, or at least less discussed in research that Barthes's first writings on literature focused on the very same question, but only from a less individual point of view. The interrogation that motivates Le Degré zéro de l'écriture (1953) and many of the essays in Essais critiques (1964) is the question of how to write, of what procedures one can follow in preparing a literary work of art, within the specific context of post-war France. These aspects in the early essays have been overshadowed first by the structural period and its focus on systematicity and conventionality, and then by the textual period and its insistence on the text and the reader as the producers of signification. However, at 
the two ends of Barthes's career one finds the same themes of writing as action and of the writer's possibilities and motivations in writing.

The hypothesis that I want to explore is that there is actually ground for a positive theory of the author in Barthes's work. By "positive" I mean that this line of thinking is not mostly interested in what the writer is not - that is, not an authority, not the granter of meaning, not the privileged participant in communication, as the essay on "the death of the author" has so clearly argued — but rather in what the writer does, what are his or her possibilities for action and the acts through which he or she sets premises for meanings to develop. By "theory" I imply that there is generality in Barthes's thinking, that his treatment of the topic transcends his own experience and those of the writers he has written about, and that his reflections can be interpreted as constituting an organized whole that offers a coherent understanding of the topic. I will not pay attention to the differences of historical context between the texts, but instead I will try to discover similarities between writings from the early and the late period. The similarities concern three themes, which will be discussed in the following order:

(1) writing as action;

(2) the need to endlessly restart writing, or the deferral of its achievement;

(3) writing as representation.

I will end my analysis with a discussion on the relationships between Barthes's positive theory of the author and some of the important concerns in recent discussions in literary criticism, addressing thus the main theme of this special issue of Sign Systems Studies, Barthes's relevance today.

\section{Writing as action}

Barthes's first work, the collection of essays Le Degré zéro de l'écriture, published in 1953, sketches a short history of French literature from the classical period to the post-war era. Barthes's approach is based on the notion of writing, écriture, which he defines as the dimension of choice and thus of liberty situated between the collective system of language and the biologically grounded style. The overall discussion is determined to a great extent by the intellectual 
debates of the time, and especially by Sartre's theory of engaged literature. This emphasis on the historical and the political seems to be far from Barthes's concerns in the Collège de France lectures in 19781980 , where his method in analysing the topic of "la préparation $d u$ roman" is based on the exploration of the subjective phantasm of writing a novel, and especially of the activities that precede the act of writing (such as taking notes), and where the historical dimension of literature is marginal if not non-existent.

Nevertheless, these differences between the early and the late work can be overcome, if Barthes's understanding of history in Le Degré zéro is clarified. In this book, Barthes reads works from the classical period and the 19th century from the point of view of the writer's condition in relation to the literary language of his or her time. What Barthes analyses are the political and cultural significations that the different forms of literary language - writing in his terminology carry along and the writer's responsibility in choosing among the different forms and their significations. Even though forms and significations change, the writer's condition, his or her responsibility in choosing a writing and thus affirming his or her social and political position, remains the same. Different historical contexts are thus linked together by this recurring general condition.

It is important to notice that writing is defined as instrumental activity in Le Degré zéro. Barthes's history of literature begins and ends with cases where the writer has at his or her disposal a form of literary representation that functions as a perfect instrument for communication. For the classical writer, writing is not a problem, since the social significations the forms of literary representation carry are concordant with the vision of the world he or she shares with the reading audience. For Camus, who marks the other end of Barthes's historical timeline, writing is also unproblematic, not because of ideological concordance, but because his écriture blanche has reached a level of semiotic non-markedness that resembles mathematical equations and permits him to "discover and deliver" (Barthes 1953: 57) the human condition without disturbing social significations. In between these two extremes cases, Barthes situates a series of writers for whom writing, the forms of literary representation at their disposal in their specific historical context, has been a problem, since they have not accepted the significations brought into the communication by the forms of literary representation. Writing is thus an instrument, but an 
instrument with a social dimension and with a history and consequently with significations that are brought into the action of writing by these dimensions. The "writer's formal identity" (Barthes 1953: 14) is based on the selection of the forms of literary representation he or she decides to use, and, metonymically, on the selection - or refusal - of the significations the forms carry with them.

Read in this way, Le Degré zéro is parallel to Barthes inaugural lecture at the Collège de France, which serves as an introduction to his further work at the institution. Barthes argues in the lecture, published as Leçon in 1978, that language and reality are incommensurable, and that the representation of the real is thus impossible, but also that this unbridgeable gap is constantly denied (Barthes 1978: 21-22). This refusal produces a continuous utopian effort to represent the real by language in literature. The devices used in this effort vary, and their changes constitute the history of literature. Like in Le Degré zéro, we find here different historical contexts linked together by a recurring general condition, defined by the fact that language and the real do not have a common measure ${ }^{1}$. If literature in general is defined in Leçon as a utopian effort to transcend this condition, to represent the real, then it is logically possible also to analyse the agents implied in this effort and their actions, that is, writers engaged in representing. This is the line of thought that leads from Le Degré zéro to Leçon and to the Collège de France lectures.

I will return to the question of representation at the end of my paper. Let us now focus on writing as action and try to see, at the level of praxis, what Barthes has to say in the Collège de France lectures about the writer's work and how the early and the late writings can complement each other. The theme of selection or of choice is present here as it was in Le Degré zéro, but it is situated at a different level. On the one hand, selection and choice determine discussions on the writer's relation to reality and its thematization in the act of writing

\footnotetext{
1 This standpoint rests on a preliminary separation of language from what is considered as real. This idea, shared by most French structural and textual theoreticians of the $60 \mathrm{~s}$ and $70 \mathrm{~s}$, is problematic, since it abstracts language from its everyday entanglement with action, experience and emotions. It is also curious, given that the theoreticians that lay their argumentation on it often understand language as having a tremendous power in conditioning thought and action. Language is first abstracted from the real, then exaggerated and finally brought back to the real just to notice that it is no more commensurable with it.
} 
down observations, impressions and ideas ('notation' in French). On the other hand, selection and choice have an important role in the writer's performative use of genres.

When Barthes analyses the role of writing down observations, impressions and ideas, he defines it as an act of marking, of drawing of boundaries and of isolation (Barthes 2003: 45-48, 137-141 ${ }^{2}$ ). From the multidimensional and layered realm of the real, the act of writing down selects certain items and isolates them from the rest. This act foregrounds epistemological and ontological commitments and the question of values. One can always ask why one item is written down and not another, what justifies the act of selection and isolation. The action is thus in need of legitimization, and this can only be based on the writer's conception of reality (ontology) and his or her personal knowledge and experience of the real (epistemology). Moreover, the further work on what is written down, the copying of notes for use in writing a literary text, thematizes their social relevance, since they become now a part of a potential act of communication. This is where writing actually begins, since the writer's private work of writing down, situated at the intersection of language, personality and the real, acquires now a social dimension. Through being copied, notations are redirected towards possible readers, their appreciation, criticism and feedback.

The act of copying, of rewriting the notes in view of the literary work to be, has to be related also to Barthes's discussion on genres. In this respect, Barthes's Collège de France lectures stand in an explicit opposition to his essays from the 1960s. If in the Essais critiques in 1964 writing was defined as an intransitive verb, meaning that writing is first and foremost linguistic activity, play with literary and ordinary language, and not oriented to the representation or communication of something that would exist prior to the text ${ }^{3}$, in Collège de France lectures Barthes writes that he is no longer sure whether this understanding is correct (Barthes 2003: 35-36, 203-209). He argues instead that one always writes something: for example a novel, a poem, or an

\footnotetext{
2 The pages are where Barthes discusses the topic most explicitly, but it runs through almost the whole volume, and other pages could thus be mentioned. This holds also for further references to Barthes 2003.

3 The introduction to Essais critiques contains, however, other comments on the writer's situation that are relevant for our purpose and are discussed in the following chapters.
} 
essay. Writing in this respect is always determined by the codified aspects of the genre, like speech is determined by the system of language.

This does not mean, however, that the writer would be entirely subjected to genre. Barthes understands in his lectures writing as a performative work on the genres. The genre functions like a codified form for the private phantasm of writing. It sets the model to follow in seeking to realize the will to write as others have done - as Proust did, as Joyce or Dante did. Genre is not only a structure or a repertoire, but rather a signifying element in a network of references that extends to the authors who have used the genre and the values they represent. It permits a mimetic identification of the writer with exemplary figures from literary history. But the realization of the genre in one's own work has also a creative dimension. The performance of genre can give rise to new emerging aspects in the literary work. In this sense, the dialectic relation of a codified genre and its realization in writing has a creative dimension that constitutes the writing subject as author. It is in relation to the genre and to those who have practiced it with success that the writer establishes his or her identity through similarity and difference at the same time, through a successful remaking of a codified form and an individual deviation from it.

\section{The deferral of achievement}

The discussion so far has put forward the first elements of a positive theory of the author. In Barthes's thinking, writing as action is selection and organization - selection among the possible forms of literary representation, marking and isolation of items to note, selection among notes to copy, their organization in regard to a potential act of communication, and choice of genres to follow, realize and transform in writing. Through these acts, the writer emerges as a cultural and social subject, as an agent that performs literary structures and categories and establishes epistemological and ontological commitments that cannot be reduced to pre-existing elements and do not acquire meaning by difference alone, but instead constitute relations of continuity and similarity that give him or her positive consistency.

Having exposed this, we can turn to the second topic, which is the need to endlessly restart writing, or the deferral of its achievement, 
based on the social and the individual condition of the writer. In Le Degré zéro de l'écriture, Barthes's diagnosis of the historical development of writing is pessimistic. All forms of literary representation acquire cultural and social significations that are foreign to the intentions of the writers who use those forms. This holds for the classical writing, which became obsolete once the classical understanding of man and society collapsed, and it holds also for Camus's écriture blanche, which will inevitably be turned into a myth by the literary institution and lose its functional purity. Literature is in this sense a pursuit of a transparent instrument that always ends in a delusion. In Leçon, Barthes defined this semiotization of form as the constituting force of literary history: it is because writing acquires historical significations that are independent in regard to its purposes of representation that writing has to be developed and experimented with (Barthes 1978: 21-22).

This conflicting relationship between a writer's intentions and the codified aspects of language and literature is at the core also in the introduction to the 1964 volume of Essais critiques (Barthes 1964: 918) which is actually one of Barthes's most substantial discussions of the writer's position and work, but which has been overshadowed by the emerging structural theory developed elsewhere in the essays. In the introduction, Barthes argues that ordinary ways of expressing emotions (his example is a letter of condolence) make, because of the conventionality of the expression, the emotions appear cold, even though they were true and expressed sincerely. The only way to communicate the singularity of the emotions is to vary the form. This is the condition of literature, and the writer resembles a friend looking for sincerity in that both are listening to their use of language and show concern for its affective effects on the listener at the level of the content expressed and of the form that expresses. In this way, literature, and all use of language as expression of emotions, is an endless play of variation, of resistance to the banality of conventions.

In the Collège de France lectures, Barthes describes a similar kind of a process of deferral of achievement, but this time it is based on the individual condition of the writer (Barthes 2003: 219-229). He applies the psychoanalytical concepts of Moi idéal and Idéal du Moi to describe what he understands as a projection of an ideal understanding of oneself as a writer, which motivates writing, but which is always deceived by the outcome of the activity. Writing is the realm of the 
Ideál $d u$ Moi, the exalting and exigent place provided by the symbolical dimension of language for the construction of oneself. The Ideál du Moi, however, does not coincide with the Moi Idéal, which is the imaginary understanding of oneself outside of writing, and which fundamentally motivates writing. This difference between the imaginary Moi Idéal and the literary representation of oneself as Idéal du $M o i$ is what makes writing an endless work. This is how Barthes describes the process:

[...] On pourrait dire que l'écrivain raisonne (ou «marche», fonctionne) ainsi: «Je veux être un type bien (Moi Idéal) et je veux que ça se dise, que ça se sache (Idéal du Moi). » [...] mais en même temps je constate que: non, ce que j'ai écrit n'est pas tout moi; il y a un reste, extensif à l'écriture, que je n'ai pas dit, qui fait ma valeur entière, et qu'il me faut à tout prix dire, communiquer, «monumentaliser», écrire: «Je vaux plus que ce que j'ai écrit.» (Barthes 2003: 222-223)

[...] One could say that the writer reasons (or "proceeds", functions) this way: "I want to be a good guy (Moi Idéal), and I want it to be said, to be known (Idéal du Moi)". [...] but at the same time I realise that: no, what I have written is not all of me; there is a surplus, extensive in relation to writing, something that I have not said and that makes my value complete, and that I will have to say at all costs, communicate, "monumentalize", write: "I am more worthy than what I wrote". 4

The notions of Moi Idéal and Idéal du Moi thus describe at the same time the individual motivation for writing literature, its deception and the need to begin writing again that it produces. The points of view in Le Degré zéro de l'écriture and the Collège de France lectures are different, but they describe basically the same phenomenon, which is the social and cultural dimension of literary semiosis as opposed to the individual one. The literary institution and the reading public will interpret texts in ways that can not be controlled by the writer, and in La mort de l'auteur Barthes forcefully stated their right to do so (Barthes 1984: 63-69). This is also true for the different forms of literary representation the writer has at his or her disposal. The literary text and its from, be it conceived as an instrument for representation or a screen for the projection of the writer's understanding of oneself, 4 All translations into English from French originals are by the author of the
article. 
stand always at the intersection of the private and the public, and mark thus the intrusion of otherness into the writer's work, which undermines the ego-logical purity and perfection of writing.

If the reader is free in interpretation only at the cost of the death of the author, as Barthes provocatively claimed at the end of the famous essay in 1968, then his reflections in the Collège de France lectures show the writer as split between two irreconcilable positions. The writer as author seeks to dominate the work and its significations, subjecting it to the logic of origin, expression and authenticity, whereas the writer as reader of his or her own work perceives the work according to the logic of textuality, as developing multiple significations that resist the paternalizing grip of authority and show the failure of the writer as author. However, despite the emphasis on the deferral of achievement, which might be interpreted as yet another element in a negative theory of the author, it has to be emphasized that Barthes's description of the social and individual deception in writing constitutes also a positive understanding of the writer. By exposing the reasons why literature is a process of quest and delusion, Barthes helps to understand what motivates the multiple acts of selection that constitute writing as action and make the writer emerge as a cultural and social subject endowed with creativeness and individual consistency. The will to write the idealized understanding of oneself and the search for transparent instruments can be adopted as hypotheses that permit to analyze motivations in a writer's series of actions, and also help to understand the writer's production as a dynamical process with intentions, coherence and rationality, even though it were an endless process of failure from the writer's point of view.

Antoine Compagnon (2002: 223-224) interprets Barthes's Moi Idéal and Idéal du Moi as establishing a typology of writers. This is clearly not the case. For Barthes, the two aspects of the self establish a logic of deferral that is common to all writing. 


\section{Writing as representation}

To consider writing as representation seems to stand in an open contradiction with what is generally considered as the core of (post)structural literary theory, namely the argument that texts are production and simulation, not representation and mimesis. Barthes himself can be regarded as a fervent partisan of the poststructural understanding of literature, and a great deal of his writings in the 1960 s and early 1970s forcefully criticize theories of realism and expression and claim that, instead of making present a message that would pre-exist the text and of depicting reality in any faithful way, literary texts are only play with codes, intertexts and rhetoric effects of reality. Nevertheless, Barthes's late works, as well as some of the early writing up to the introduction to Essais critiques, can also be read as reflection on literature as representation. In order to understand this, it is necessary to define what he actually means by representation in these works and especially what he understands as the object of representation. This discussion will then lead us back to the question of the author.

It is common to discuss representation as a relation between the world and the text, to consider it as linguistic description or narration of characters, events or settings, of things and processes that are not linguistic themselves and that exist somehow independently of the text, and to judge the success of representation in terms of equivalency or concordance between the depiction offered by the text and the nontextual understanding of the items represented. Seen in this way, representation is evidently difficult, if not impossible, since the very notion depends on a primary separation of language and reality and the secondary effort to make them match again. As Barthes wrote in his inaugural lecture at the Collège de France, language is onedimensional and the world is multidimensional and thus the effort to make them meet in representation is a utopian wish (Barthes 1978: 21-22).

But this is not the idea of representation we find in Barthes's late works, nor in some of the early ones. Here it is not the question of representing real persons, actions or settings by linguistic means; instead, it is the question of affects and their communication by the means of literature, and of a search for transcendence by these means. In the introduction to Essais critiques, Barthes claims that writing is 
motivated by desire and understands it first of all as a form of communication. It is because the conventionality of language and of forms of writing intervenes in the communication process and threats the originality and singularity of the emotion to be expressed that writing becomes a work on language. Only through a play of variations of form one can wish to convey one's emotions to the addressee in an exact way. Seen from this perspective, Barthes's (post)structural period and his theory of textuality, initiated by Essais critiques, can be considered as derived, if not even based on, an understanding of literature as communication and expression.

During the $70 \mathrm{~s}$, Barthes moved gradually from an antirealist textual paradigm towards a more moderate understanding of literature. This process was accelerated by the death of his mother, soon after he had been elected to the Collège de France. It seems as if, after this acute loss, it would have been difficult to speak of the real as consisting of codes, citations and intertexts only. The late essays and the Collège de France lectures do not propose a return to the naïve theories of representation that were criticized earlier. Rather, they propose a theory of literary texts as mediated representations of emotions and affects, and especially of "moments of truth", which Barthes sees as represented in works by for example Proust, Gide, Stendhal, Tolstoi and Fellini (Barthes 2003: 40-41 and 151-161, Barthes 2002: 177-180). These moments can be described as emotional crises where the subject is confronted, on the one hand, with the bare finitude of bodily human existence, and above all with sickness and death, and, on the other hand, with manifestations of deep emotions, such as pity and love. These moments can find in writing a literary representation that gives them form and the power to move the reader, so that the "moment of truth" can not actually be separated from its writing, and becomes shared in the act of reading. Barthes describes this as follows:

Au plan de l'écriture: Moment de vérité = solidarité, compacité, fermeté de l'affect et de l'écriture, bloc intraitable. Le Moment de vérité n'est pas dévoilement, mais au contraire surgissement de l'ininterprétable, du dernier degré de sens, de l'après quoi plus rien à dire [...]. (Barthes 2003: 159)

At the level of writing: Moment of truth = solidarity, compactness, strong hold between affect and writing, inseparable unity. The moment of truth is not 
unveiling, but on the contrary appearance of what can not be interpreted, of the last degree of signification, of the after which nothing more to say [...].

Let us point out two aspects in this citation. Firstly, it is important to notice that the inseparability of the affect and its writing establishes a specific type of temporality. The "moment of truth" is not revealed in writing, as if writing would only be a means for the communication of something that exists independently of the text and before it; on the contrary, "the moment of truth" emerges in writing, acquires consistency in writing. In this sense, representation is a creative process, although it is also a process of giving of form to an affect that is not itself literary or linguistic. Writing makes a qualitative difference: an affect represented is also at least potentially shared, communicated, and thus transcends the finitude of individual experience. Secondly, it is important to see that the "moment of truth" marks also the limit of interpretation. It is the last degree of signification, the appearance of something that cannot be further explained. What this means is that, like the obtus and the punctum, the moment of truth defies the generality of codes and sign systems and resists paraphrases. It belongs to the domain of the singular and the momentary, and is as such opposed to rational explanations that seek to integrate all the elements of the text within one interpretative perspective. In this sense, it demands a new type of pathetic critical reading that is based on the punctual moments in the text and seeks to understand their value and force.

This, however, does not mean that the "moments of truth" would only take shape as opposed to the structural elements of narration and the codified elements of the genre and language. In one of his unfinished and posthumously published essays, On échoue toujours à parler de ceux qu'on aime (One always fails to speak of the beloved ones, Barthes 1984: 353-363), Barthes discusses Stendhal's love for Italy and the problems in its representation. According to Barthes, Stendhal's travel books on Italy failed, because they sought to give a direct expression to the emotion, and were consequently reduced either into stereotypical representations, or then into aphasia. Instead, Stendhal managed to represent the emotion in his novel La chartreuse de Parme, because the narrative and the symbolical structure of the novel permitted him to transcend his private situation and to express the emotion in a mediated form that made it not only readable and 
interpretable by others, but also felt, experienced. The novel as genre permits thus not only the shaping of the writer's identity through performance, as was discussed earlier, but also the representation of the affect, through its narrative and symbolical structures that give the affect form, consistency and transcendence.

In the Collège de France lectures, Barthes emphasises further the interpersonal ethical relationship this search for communication of affects implies. According to Barthes (2003: 225-227), the recognition of the other that the reader is constitutes a necessary condition for transcendence in the act of writing. The writer can not seek communication of affects and acknowledgement for his or her value (the Moi Ideál) without a preliminary acknowledgement of the value of the others. If this condition is satisfied, the novel - and Barthes in inclined to include in the genre all works that seek the transcendence of egotism - can become an occasion for a relationship of "mimetic sympathy" (Barthes 2003: 226) between the writer and the reader. Again, literature is understood as communication, but not in the sense of a simple transfer of pre-existing emotions, but as a search for communion where the effect produced in reading corresponds to the emotion that motivates writing. ${ }^{6}$ Since the only way to attain this is through taking into account the reader in writing, one can finally say that the birth of the writer can only be at the cost of the birth of the reader.

\section{Barthes positive theory of the author and its relevance today}

Barthes theory of the representation of affects may give rise to critical and even sceptical comments. One may ask whether there really is transcendence, or even communication in this process, or whether it is rather a question of the reader's private experiences only. What gives rise to the "moment of truth" in reading may originate in calculated use of literary devices from the writer's part; the experience in writing and in reading may not meet, and the reader may fall in the trap of emotional fallacy.

See also Miller (1992: 49-51), who argues that in Barthes's novelesque writing the relationship between the writer and the reader is above all erotic. 
These remarks may hit a point, but they still are not, in my opinion, enough to disregard Barthes's insights. Literature certainly is communication at risk, a process where the end product is rarely if ever similar to the original. Barthes's reflections on the social and cultural semiosis of form give ample ground to defend this position. But dissemination is not a handicap; it is rather an advantage. The fact that literature offers a mediated way to represent emotions and affects may be exactly the factor that makes it suitable for the exploration, development and analysis of aspects of human existence that do not easily find place in other forms of representation or discourse. This is especially the case in the novel which as a genre permits a specific heterology of true and false (Barthes 2003: 161). The delegation of action, emotions, and commitments of all kinds to characters and narrators may be exactly the reason why literature permits writers to reveal, expose and narrate different aspects of human existence, from the sublime to the scatological.

Barthes makes this point in the essay on Stendhal. A similar kind of argument is made by Jørgen Dines Johansen in his recent book Literary Discourse. A Semiotic-Pragmatic Approach to Literature (2002). Dines Johansen argues that literature as mediated representation permits a specific type of exploration of aspects of human existence. It is because the subjectivity in the text is and is not concomitant with the subjectivity of the author that writers can at the same write about their innermost experiences and do it in veiled forms sheltered by poetic licence that screen off simple identifications. Like Barthes, Dines Johansen also considers the search for transcendence as one of the fundamental raisons d'etre of literature. Writing can be motivated by the will to overcome time and by the will to give a public, shared and durable expression to emotions and experience and their objects; it can be an effort to bear witness. Interestingly, Dines Johansen's frame theory is Peirce's doctrine of signs, whereas Barthes remained faithful to structural methodology all through his career. It is in considering literature as action and writers as agents involved in this action that the Peircean and the Saussurean traditions of semiotics seem to best support each other.

From Le Degré zéro until the last texts Barthes emphasized that writers' action takes place in historical contexts, and that these historical contexts are semiotic situations. Each act makes sense in relation to cultural and social significations that are local and temporal, and for 
research on authors to make sense these factors have to be recognized. This argument is made also by Antoine Compagnon in the chapter he dedicates to the author in Le Démon de la théorie. Littérature et le sens commun (1998). He argues also for ethical responsibility towards the author. If writing is a historically situated and bodily grounded activity that is motivated by the will to bear witness, the reader may not be entitled to treat texts just as any objects. Literary texts are intentionally produced entities shaped by processes of selection and organization carried out by authors in specific contexts. Literary research can study these factors, but it can also disregard them. The choice is a scientific one, and an ethical one. Barthes's call for pathetic criticism is here in line with Compagnon's argumentation. Furthermore, Barthes helps to understand the inherently delusive logic at work in writing. Writing is, on the one hand, performative work on genres, application, realization and transformation of coded forms of narration and description. On the other hand, writing can give rise to deception only, since the Idéal du Moi and the Moi Idéal never meet. Subjectivity — the subjectivity of the author — thus emerges in writing, but in an inherently deceptive process marked by a continuous deferral of perfection.

Literary theory has been under attack during the past years. Scholars have argued that theoretical reflection has become a speculative musing detached from "real" concerns (Eagleton 2003; Patai, Collar 2005). It is not rare to mention Barthes in these occasions. Barthes's reflections on the author show, however, that theoretical sophistication need not deprive literary research of concerns that are vital and real, such as loss, suffering, love and desire, and their communication. It has been my intention in this article to show that Barthes's work, which has in some occasion been unfairly reduced to the essay $L a$ mort de l'auteur and other militant writings from the textual period, provides basis for a positive theoretization of the writer's work and position within the literary field. The question of the author runs through Barthes career, stimulating reflection on possibilities and impossibilities of expression, communication, and communion. The posthumously published Collège de France lectures, due to their sketchy, unfinished nature, show us Barthes at the work of thinking, before ideas coalesce in their final form. In the introduction to the Essais critiques, Barthes wrote that the "the material text (the Book) may have, from the writer's point of view, an unessential character" 
(Barthes 1964: 11). The same holds for theory. The point is not to establish the final theory, but to continue coherent and general reflection that debunks naiveties and exposes complexities. Barthes work shows how to continue in this line in theorizing the author.

\section{References}

Barthes, Roland 1953. Le Degré zéro de l'écriture. Paris: Seuil.

- 1964. Essais critiques. Paris: Seuil.

- 1978. Leçon. Paris: Seuil.

- 1984. Le bruissement de la langue. Paris: Seuil.

- 2002. Comment vivre ensemble. Cours au Collège de France (1976-1977). Paris: Seuil \& IMEC.

- 2003. La Préparation du roman I et II. Cours et séminaires au Collège de France (1978-1979 et 1979-1980). Paris: Seuil/IMEC.

Brenner, Jacques 1993. Le roman français de 1960 à 1990. In: Le roman français contemporain. Paris: Ministère des Affaires Etrangères.

Buffat, Marc 2002. L'Aventure sémiologique. Revue des Sciences Humaines 268 : $27-39$.

Comment, Bernard 1991. Roland Barthes, vers le neutre. Paris: Bourgeois.

Compagnon, Antoine 1998. Le démon de la théorie. Littérature et le sens commun. Paris: Seuil.

- 2002. Le Roman de Roland Barthes. Revue des Sciences Humaines 266/267: 203-231.

Eagleton, Terry 2003. After Theory. London: Penguin.

Johansen, Jørgen Dines 2002. Literary Discourse. A Semiotic-Pragmatic Approach to Literature. Toronto: Toronto University Press.

Knight, Diana 2002. Vaines pensées: la Vita Nova de Barthes. Revue des Sciences Humaines 268: 93-107.

Miller, D.A. 1992. Bringing out Roland Barthes. Berkeley: University of California Press.

Patai, Daphne; Corral, Will H. 2005. Theory's Empire. An Anthology of Dissent. New York: Columbia University Press.

\section{Положительная теория автора у Барта}

Общеизвестно, что Ролан Барт посвятил свою последнюю серию лекций в Коллеж де Франс подготовке романа, но гораздо меньше знают, что и его первые работы о литературе сосредоточивались на той же теме, хотя и с менее индивидуалистской точки зрения. Вопросы, как писать и какие процедуры соблюдать в ходе подготовки 
художественного произведения, являются основой развития мысли как в «Нулевой степени письма» (1953) так и для многих эссе в сборнике «Критические эссе». Как в начале, так и в конце карьеры Барта рассматриваются темы: письмо как действие и возможности и мотивация автора при писа́нии. В настоящей статье делается попытка доказать гипотезу, что в работах Барта наблюдаются начала положительной теории автора. Статья изучает совпадения между ранними и поздними работами Барта в трех аспектах: 1) письмо как действие; 2) задержка продукта письма; 3) письмо как репрезентация. Статья заканчивается рассуждением о положительной теории автора у Барта и о ее связях с новейшими дебатами в современной теории литературы.

\section{Barthes'i positiivne autoriteooria}

On teada-tuntud tõsiasi, et Roland Barthes pühendas oma viimase loenguteseeria Collège de France'is romaani ettevalmistamise teemale, kuid märksa vähem teatakse seda, et ka tema esimesed kirjutised kirjandusest keskendusid samale teemale, ehkki vähem individuaalsest vaatenurgast. Küsimused, kuidas kirjutada ja milliseid protseduure kunstiteose ettevalmistuse käigus järgida, on aluseks mõttearendustele Kirja nullastmes (1953) ja paljudes esseedes kogumikus Kriitilised esseed. Nii Barthes'i karjääri lõpus kui alguses leiavad käsitlemist teemad nagu kirjutamine kui tegevus ja autori võimalused ning motivatsioon kirjutamisel. Käesolev artikkel üritab tõestada hüpoteesi, et Barthes'i teostes on täiesti olemas positiivse autoriteooria alged. Artikkel uurib sarnasusi Barthes'i varaste ja hiliste tööde vahel kolmes valdkonnas: (1) kirjutamine kui tegevus; (2) kirjutamise saaduse viibimine; ja (3) kirjutamine kui esitus. Artikkel lõpeb arutlusega Barthes'i positiivsest autoriteooriast ja selle seostest kaasaegse kirjandusteooria uusimate aruteludega. 